\title{
MEASUREMENT OF TOTAL WATER EXCHANGE ${ }^{1}$
}

\author{
By L. H. NEWBURGH, MARGARET WOODWELL JOHNSTON AND \\ MARK FALCON-LESSES
}

(From the Department of Internal Medicine, Medical School, University of Michigan,
Ann Arbor)

(Received for publication July 1, 1929)

As a rule when the terms, "water balance" or "water exchange," occur in clinical literature, the writer has in mind merely a comparison between the water which enters the body as food and drink with the water which leaves it as urine. Sometimes the water of the stool is also included. -A statement that includes merely these increments of water is inaccurate and liable to be misleading, since it fails to take into account (1) the large amount of water that is evaporated from the skin and lungs; (2) the water that is formed by oxidation of the food; (3) water physically held as part of the protoplasm, but set free when the organism derives some of its energy by burning its own tissues.

\section{I}

We propose to describe a system which permits the observer to obtain an accurate account of all the sources and the total amount of water that becomes available for the organism on the one hand; and of the amount of water that leaves the organism on the other hand.

In working out a plan for dealing with all the increments of water, it is helpful to think of them under two separate headings: (1) Those that may be measured by standard laboratory methods; and (2) those whose value is obtained indirectly by calculation. The first group includes the water that the subject drinks as such, and the water contained in the food, urine and stool. The second group consists of the water evaporated from the skin and lungs, the water that is a byproduct of the combustion of materials, and water made free when body tissue is burned.

${ }^{1}$ Aided by a grant from The Fellowship Corporation. 
In order to determine whether the organism has gained or lost water, it is necessary to classify the above mentioned portions of water under two headings. On one side of the balance sheet are gathered together all those increments of water that have become available as free water for the first time during the period. They include not only the water that enters the organism from the outside, but also the water formed by oxidation of the metabolic mixture, ${ }^{2}$ and the water that is freed when body tissues are burned (preformed water). On the other side of the balance sheet all the fractions of water that have been given off by the organism, are brought together. They are the water of the urine and stool and the water that has been given off by

TABLE 1

Water exchange

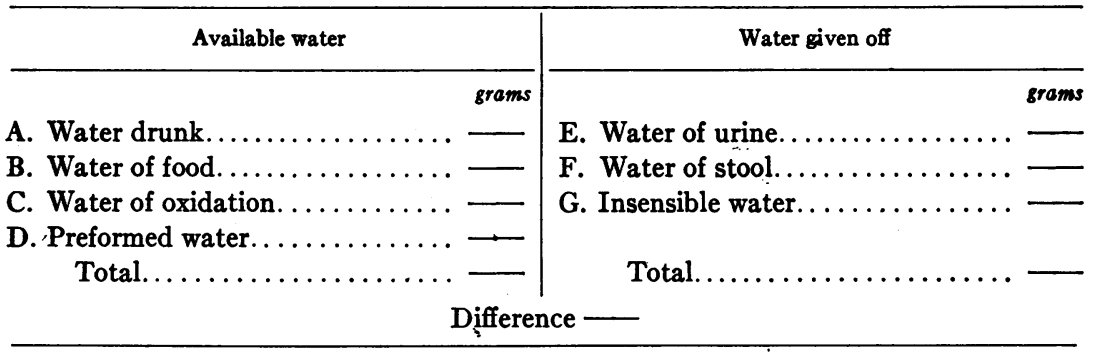

the skin and lungs ${ }^{3}$ (insensible water). Table 1 is a water balance form that was found useful.

The weights of each of these seven items of water were obtained in the following manner:

$A$. The subject drank water as desired from a "thermos bottle" fitted with a rubber stopper containing a glass drinking tube. The stoppered bottle filled with cold water was weighed at the beginning of the period and again at the end on a balance accurate to one gram. Less than one gram of water evaporated from the bottle in twentyfour hours.

$B$. Several different diets were used. The best results were obtained when only milk and sucrose was fed. During this period, the

${ }^{2}$ The metabolic mixture consists of all the materials burned by the organism during the period and thus often includes body tissues.

${ }^{3}$ This water is chiefly or entirely removed from the body by evaporation, but it also includes any water lost as liquid sweat. 
desired composition was secured by mixing appropriate amounts of cream (40 per cent), whole milk and skim milk. After thorough mixing a sample was removed. Its water content was determined by freezing and desiccation in vacuo (1). The sucrose was considered to be dry.

At other times the diet included bread, butter and bananas in addition to the milk mixture and sugar. Samples of banana were frozen and desiccated. The water content of the bread was determined by drying in the oven. Since the butter contained, at most, two grams of water, its water was not regularly determined. Fifteen per cent of its weight was allowed for water. ${ }^{4}$

Finally we were interested to know what results could be obtained when the usual types of food were employed instead of the highly

TABLE 2

Insensible water

\begin{tabular}{|c|c|c|c|}
\hline I & & II & \\
\hline & grams & & zrams \\
\hline Subject at beginning $\ldots \ldots \ldots \ldots \ldots$ & - & Subject at end.... & \\
\hline Food............... & - & Urine $y . . . \ldots$. & \\
\hline 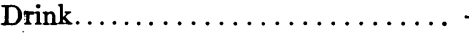 & - & Stool. .............. & - \\
\hline 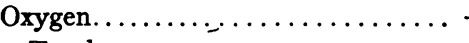 & $\longrightarrow$ & Carbon dioxide.......... & - \\
\hline Total........... & - & Total.......... & - \\
\hline
\end{tabular}

restricted diets just described. Accordingly the standard vegetables, fruits, meats, milk, eggs, bread and butter, cooked in the customary way, were fed. Complicated desserts and salad dressings were omitted. Since it seemed hopeless to obtain a fair sample from such a complicated mixture, the water content was determined as follows: A dietitian prepared two diets as nearly alike as she could. All that the subject was to receive at any meal was placed on a tray and the whole weighed. After the subject had eaten, the tray and dishes were weighed again. The duplicate diet was also placed on a tray which was then weighed. The food was next scraped into an enameled can of known weight, and the covered can was placed in a refrigerator.

${ }^{4}$ In order to get accurate knowledge of the composition of the diet, a sample of the milk mixture was analysed for nitrogen (Kjeldahl), fat by the Babcock method, and ash. Samples of the dry bread and bananas were analysed for nitrogen. 
The subject received three meals daily and the duplicate diet was also served in three portions, weighed and collected in the can. The latter was then weighed with the whole wet duplicate diet in it and placed on a steam bath whose temperature varied from $50^{\circ}$ to $70^{\circ} \mathrm{C}$. It took about two weeks to reach its final weight. The loss was assumed to have been caused entirely by evaporation of water. However such "dry" diets ${ }^{5}$ lost an additional small amount of weight after being in a desiccator over sulphuric acid.

TABLE 3

Constants to obtain oxygen absorbed and carbon dioxide given off

\begin{tabular}{ll}
\hline \multicolumn{2}{c}{ Oxygen } \\
Multiply protein & by 1.38 \\
Multiply fat & by 2.86 \\
Multiply carbohydrate by 1.13 \\
Carbon dioxide \\
Multiply protein $\quad$ by 1.46 \\
Multiply fat & by 2.78 \\
Multiply carbohydrate by 1.54 \\
\hline
\end{tabular}

$C$. The weight of the water that arises from protein, fat or carbohydrate when they are oxidized by the organism, has been determined by several students. We used the following values (2).

$\begin{array}{ll}100 \text { grams protein } & \text { yields } 41 \text { grams } \mathrm{H}_{2} \mathrm{O} \\ 100 \text { grams fat } & \text { yields } 107 \text { grams } \mathrm{H}_{2} \mathrm{O} \\ 100 \text { grams carbohydrate yields } 60 \text { grams } \mathrm{H}_{2} \mathrm{O}\end{array}$

It is, however, necessary to know the metabolic mixture before this increment of water can be calculated. The method of calculating the former has already been described (3).

$D$. To obtain the preformed water the diet and the metabolic mixture are compared. When the former contains more energy than the latter and when no body protein is destroyed or when the caloric value of the two is the same, no preformed water is released. When, however, a submaintenance diet is fed, the destruction of body tissues frees the water that was physically held by them. But under

${ }^{5}$ All of the dry duplicate diet collected during a period was ground and a sample analysed for nitrogen. 
TABLE 4

Weight of oxygen added to body to complete oxidation of metabolic mixture

A. Protein (Muscle protein)

Composition (4)

$\mathrm{C}=51$ per cent $\left\{\begin{array}{l}\text { Respiratory } 40 \text { per cent } \\ \text { Urine and feces } 11 \text { per cent }\end{array}\right.$

$\mathrm{H}$ to form water $=4.8$ per cent

$\mathrm{O}=21$ per cent

1 gram $\mathrm{C}$ requires 2.66 grams $\mathrm{O}$ to form $\mathrm{CO}_{2}$

1 gram $\mathrm{C}$ requires 1.33 grams $\mathrm{O}$ to form urea

1 gram $\mathrm{H}$ requires 8.0 grams $\mathrm{O}$ to form water therefore

(a) Protein $\times(0.40 \times 2.66)=\mathrm{O}$ to form $\mathrm{CO}_{2}$

(b) Protein $\times(0.11 \times 1.33)=0$ to form urea

(c) Protein $\times(0.048 \times 8.0)=\mathrm{O}$ to form $\mathrm{H}_{2} \mathrm{O}$

(d) Protein $\times 0.21=$ intramolecular $\mathrm{O}$

$(\mathrm{a}+\mathrm{b}+\mathrm{c})-(\mathrm{d})=1.384$, hence

Protein $\times 1.38=$ Oxygen added

B. Fat (tripalmitin)

Composition

$\mathrm{C}=76$ per cent

$\mathrm{H}=12$ per cent

$\mathrm{O}=12$ per cent

(a) Fat $\times(0.76 \times 2.66)=0$ to form $\mathrm{CO}_{2}$

(b) Fat $\times(0.12 \times 8.0)=\mathrm{O}$ to form $\mathrm{H}_{2} \mathrm{O}$

(c) Fat $\times 0.12=$ intramolecular $\mathrm{O}$

$(\mathrm{a}+\mathrm{b})-(\mathrm{c})=2.86$, hence

Fat $\times 2.86=$ Oxygen added

C. Carbohydrate (sucrose)

Composition

$\mathrm{C}=42$ per cent

$\mathrm{H}=6.5$ per cent

$\mathrm{O}=51.5$ per cent

(a) $\mathrm{CH} \times(0.42 \times 2.66)=0$ to form $\mathrm{CO}_{2}$

(b) $\mathrm{CH} \times(0.065 \times 8.0)=\mathrm{O}$ to form $\mathrm{H}_{2} \mathrm{O}$

(c) $\mathrm{CH} \times 0.515=$ intramolecular $\mathrm{O}$

$(\mathrm{a}+\mathrm{b})-(\mathrm{c})=1.125$, hence

Carbohydrate $\times 1.13=$ Oxygen added

Weight of carbon dioxide yielded by the metabolic mixture
A. Protein
Protein $\times(0.40 \times 3.66)=\mathrm{CO}_{2}$
B. Fat
Fat $\times(0.76 \times 3.66)=\mathrm{CO}_{2}$
C. Carbohydrate
$\mathrm{CH} \times(0.42 \times 3.66)=\mathrm{CO}_{2}$ 
these circumstances the total amount of preformed water released can not be calculated while glycogen is being destroyed, since it is not known how much water it binds. In the previous paper (3) we pointed out the ways by which we believed we had selected periods during which no glycogen (or a very few grams) was being oxidized.

Comparison between the ingoing and outgoing nitrogen shows whether body protein has been destroyed. It is customary to allow three grams of preformed water for every gram of protein. The remainder of the calories furnished by the body come from fat. Its preformed water is considered to be about ten per cent of its weight.

$E$. The water content of the urine was obtained by freezing and desiccating, in vacuo, duplicate samples of each twenty-four hourly amount, by means of the same technique employed for milk.

$F$. The subject defecated directly into a weighed enameled container by means of a commode. After recording the weight of the container plus the wet stool, the whole was placed on the steam bath without transfer. The loss of weight, which was complete in three or four days, was assumed to be entirely due to evaporation of water. ${ }^{6}$

$G$. We have obtained the weight ${ }^{7}$ of the insensible water by adding

${ }^{6}$ All of the feces formed while any single diet was being used was mixed, ground and analysed for nitrogen. When the subject received only the milk mixture and sugar, fat and fecal ash was also determined.

${ }^{7}$ Since the time of Sanctorius (1614) it has been known that there is a continuous loss of gaseous material from the body. Later studies have shown that this consists of carbon dioxide and water vapor. The combined weight of these two is greater than the weight lost by the organism as determined by the scales. (The terms "Insensible loss" or "Insensible perspiration" refer to the latter.) This is true because the loss of weight caused by the outward passage of carbon dioxide and water, is, in part, compensated for, by the weight of the oxygen absorbed.

Isenschmid (5) has expressed this relationship thus:

$$
\text { Insensible loss }=\mathrm{H}_{2} \mathrm{O}+\mathrm{CO}_{2}-\mathrm{O}_{2} \text {. }
$$

If carbohydrate alone were being burned the weight of oxygen absorbed would equal the weight of the oxygen contained in the carbon dioxide given off. Under these conditions the insensible loss would equal the weight of the water plus carbon.

When, as is usually the case, fat and protein are burned, some of the oxygen absorbed is used to complete the oxidation of hydrogen as well as carbon. Then the insensible loss may be thought of as made up of water, carbon and hydrogen. Schwenkenbecher and Inagaki (6) pointed out this relationship in 1905.

Because of this varying relationship it is not possible to determine the total 
the weight of everything that entered the body during the period to its weight at the beginning; and by adding the weights of everything that left the body during the period, other than water vapor, to its weight at the end of the period. The difference between the two sums is clearly the weight of the water lost insensibly. Table 2 shows what weights need to be used. The manner of obtaining the weights of the subject, food, drink, urine and stool, has already been described.

The weight of the oxygen is obtained by calculating how much of it had to be added to the body to complete the oxidation of the metabolic mixture; and the weight of the carbon dioxide is derived by means of the same type of calculation. The time required for these cumbersome calculations may be greatly reduced by means of numerical constants.

Table 3 shows the constants ${ }^{8}$ we have used. These constants were obtained by the calculations shown in table 4 .

\section{II}

When it was desired to obtain the day to day water exchange of an individual we proceeded as follows:

1. The mean twenty-four hourly heat production was determined (3).

2. The metabolic mixture was calculated from this value, the composition of the diet and the outgoing nitrogen.

3. Next the weights of the oxygen absorbed and carbon dioxide given off on the basis of this mixture were obtained, and the oxygen value subtracted from that for carbon dioxide.

4. The subtraction of this latter difference from each twenty-four hourly insensible loss gives the weight of the water lost insensibly during each twenty-four hours.

5. The water formed by oxidation of the metabolic mixture was calculated.

insensible water by merely deducting the weight of the carbon of the metabolic mixture from the insensible loss. The oxygen and carbon dioxide may be determined directly or calculated from the metabolic mixture. With the weights of the insensible loss, the carbon dioxide and oxygen, the insensible water may be obtained from Isenschmid's Equation.

${ }^{8}$ Lusk (Science of Nutrition, 3rd ed., p: 28) states that it requires 133.43 grams oxygen to burn 100 grams meat protein; 288.5 grams oxygen for 100 grams fat; and 118.5 grams oxygen for 100 grams starch. 
6. The diet was compared with the metabolic mixture and the differences used to calculate preformed water, if body tissue was being oxidized; or if tissue was being added to the body, the appropriate amount of water (stored by it) was subtracted from the total available water.

The use of an average metabolic mixture for the period instead of calculating one for each twenty-four hours has two advantages. It tends to compensate for any irregularities of absorption and oxidation and so probably gives a better statement of what has been metabolized. Further, it greatly reduces the time required for calculation.

III

A concrete example of the way in which water exchange was determined will now be given.

The normal subject and the general conduct of the study have already been described (3). From January 3 to January 8, 1929, his life and diet were unrestricted. The evening of January 8 he went to bed in the special room, and the next morning began to receive a milk mixture and sugar in amounts which were expected to be close to his requirement for maintenance.

The water exchange was determined for five consecutive days beginning January 11. During this time the milk mixture was found by analysis to contain 69 grams of protein, 83 grams of fat and 112 grams of carbohydrate, per day. In addition he received 155 grams of sucrose daily. The average twenty-four hourly heat production was 1907 calories. The diet yielded 2091 calories; and he destroyed 11.88 grams of body protein daily. The subtraction of the out-going calories from the calories of the diet plus those of the body protein, left 232 calories to be stored. For purposes of calculation it is assumed that they are stored as fat. This represents the storage of 24 grams of fat; or an addition to the body weigh: of 26 grams. On the other hand he lost 11.9 grams of protein from the body daily, which, with its water, represents a loss of $\mathbf{4 8}$ grams. Therefore, he should lose 22 grams of weight daily. His metabolic mixture was 81 grams protein (diet plus body protein); 267 grams carbohydrate (it is assumed that all the carbohydrate of the diet was burned); and 57 grams of fat (to supply the difference between the outgoing calories and the sum of the 
calories derived from the protein and carbohydrate oxidized). From the above it is evident that there was released the water which was held by the 11.9 grams of body protein destroyed daily. That is an addition of 36 grams to the available water. On the other hand he stored 24 grams of fat which holds 2 grams of water; so that we may consider that 34 grams of preformed water became available.

The water formed by the oxidation of this metabolic mixture (obtained by means of the constants mentioned above) was 254 grams.

By means of the constants in table 3 it is found that the oxygen absorbed to complete the oxidation of the metabolic mixture weighed 576.5 grams and the carbon dioxide produced weighed 687.9 grams. The difference is 111 grams. The subtraction of this value from the twenty-four hourly insensible loss gives the daily insensible water.

Since the diet was unusual it was thought that the standard method of calculating the available calories of the diet might not be sufficiently accurate. For this reason the calories actually lost in the stool were determined by the oxy calorimeter of Benedict and Fox ${ }^{9}(7)$. The calories lost in the urine were calculated by multiplying the urinary $\mathrm{N}$ by 8 , (following the custom of the Carnegie Institution). The caloric value of the stool was 4.35 calories per gram of dry weight. The total calories lost in the stool and urine for the period were 979 or 196 per day. The full heat value of the diet was obtained by multiplying protein by 5.65 ; fat by 9.54 and carbohydrate by 4 . To this value was added the calories derived from body protein, making a total of 2317 daily. From this must be substracted the calories lost in urine and stool, leaving 2121 calories for metabolic disposal. The twenty-four hourly calories determined by insensible loss were 1907 .

Since the full heat value has been assigned to the materials oxidized, the calories of the metabolic mixture in this case must consist of the total heat production plus the potential heat lost in the urine and stool, that is, $1907+196=2103$. The metabolic mixture would accordingly be protein 81 grams, fat 61 grams and carbohydrate 267 grams. The only difference between the metabolic mixtures calculated by the two methods is four grams of fat. With the latter mix-

\footnotetext{
${ }^{9}$ We are indebted to Dr. T. M. Carpenter of the Nutrition Laboratory of the Carnegie Institution for this determination.
}

THE JOURNAL OF CLINICAL INVERTIGATION, VOL. VIII, NO. 2 
TABLE 5

Data used in calculation of water exchange

\begin{tabular}{|c|c|c|c|c|c|c|c|c|c|c|c|c|}
\hline \multirow{2}{*}{ Date } & \multirow{2}{*}{$\begin{array}{c}\text { Wêight } \\
\text { of } \\
\text { subject } \\
8: 40 \\
\text { a.m. }\end{array}$} & \multirow[b]{2}{*}{ 总 } & \multicolumn{2}{|c|}{ Milk* } & \multicolumn{3}{|c|}{ Urine } & \multicolumn{3}{|c|}{ Stool } & \multirow{2}{*}{ 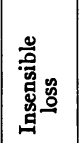 } & \multirow{2}{*}{ 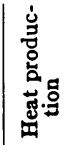 } \\
\hline & & & $\begin{array}{l}\vec{J} \\
\stackrel{0}{0}\end{array}$ & 总 & $\begin{array}{l}\text { Jే } \\
\stackrel{0}{\circ}\end{array}$ & : & $z$ & 丞 & : & $z$ & & \\
\hline 1928 & grams & grams & grams & $\begin{array}{l}\text { per } \\
\text { cent }\end{array}$ & grams & grams & grams & grams & grams & grams & grams & $\begin{array}{c}\text { calo- } \\
\text { ries }\end{array}$ \\
\hline January 11 . & 59,520 & 268 & 2,299 & 87.8 & 1,527 & 45 & 12.04 & 122 & 17.5 & $0.72 \dagger$ & 1,213 & 2,040 \\
\hline January 12 . & 59,385 & 724 & 2,200 & 87.5 & 2,182 & 49.6 & 12.33 & 0 & & 0.72 & 1,073 & \\
\hline January 13. & 59,210 & 300 & 2,198 & 87.5 & 1,194 & 44.6 & 12.69 & 0 & & 0.72 & 1,078 & 1,870 \\
\hline January 14. & 59,590 & 368 & 2,201 & 87.5 & 1,376 & 41.7 & 11.76 & 22 & 6.5 & 0.72 & 1,175 & 1,990 \\
\hline $\begin{array}{l}\text { January } 15 . \\
\text { January } 16 .\end{array}$ & $\begin{array}{l}59,740 \\
59,785\end{array}$ & 407 & 2,200 & 87.3 & 1,504 & 42.6 & 11.60 & 205 & 55 & 0.72 & 1,009 & 1,775 \\
\hline
\end{tabular}

* To obtain total weight of food, add 155 grams daily for sucrose.

$\dagger$ Total mixed stool analysed in duplicate for $\mathrm{N}$ and apportioned per day.

TABLE 6

Water exchange of a normal subject. Diet more than maintenance

\begin{tabular}{|c|c|c|c|c|c|c|c|c|c|c|}
\hline & (1) & (2) & (3) & (4) & (5) & (6) & $(7)$ & (8) & (9) & (10) \\
\hline Date & 站 & 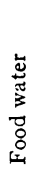 & 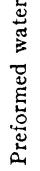 & 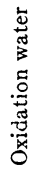 & 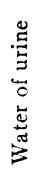 & 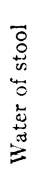 & 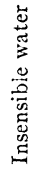 & 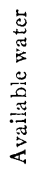 & 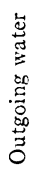 & 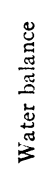 \\
\hline
\end{tabular}

Available energy of diet calculated by standard method

\begin{tabular}{l|r|r|r|r|r|r|r|r|r|r}
\hline & grams & grams & grams & grams & grams & grams & grams & grams & grams & \\
January $11 \ldots \ldots \ldots \ldots \ldots \ldots$ & 268 & 2,018 & 34 & 254 & 1,482 & 105 & 1,102 & 2,574 & 2,689 & -115 \\
January $12 \ldots \ldots \ldots \ldots \ldots$ & 724 & 1,925 & 34 & 254 & 2,132 & & 962 & 2,937 & 3,094 & -157 \\
January $13 \ldots \ldots \ldots \ldots \ldots$ & 300 & 1,923 & 34 & 254 & 1,149 & & 967 & 2,511 & 2,116 & +395 \\
January $14 \ldots \ldots \ldots \ldots \ldots$ & 368 & 1,926 & 34 & 254 & 1,334 & 16 & 1,064 & 2,582 & 2,413 \\
January $15 \ldots \ldots \ldots \ldots \ldots$ & 407 & 1,921 & 34 & 254 & 1,461 & 150 & 898 & 2,616 & 2,509 & +107 \\
\hline
\end{tabular}

Available energy of diet calculated from full heat value of food, stool and urine

\begin{tabular}{l|r|r|r|r|r|r|r|r|r|r}
\hline January $11 \ldots \ldots \ldots \ldots \ldots$ & 268 & 2,018 & 34 & 259 & 1,482 & 105 & 1,101 & 2,579 & 2,688 & -109 \\
January $12 \ldots \ldots \ldots \ldots \ldots \ldots$ & 724 & 1,925 & 34 & 259 & 2,132 & & 961 & 2,942 & 3,093 & -151 \\
January $13 \ldots \ldots \ldots \ldots \ldots \ldots$ & 300 & 1,923 & 34 & 259 & 1,149 & & 966 & 2,516 & 2,115 & +401 \\
January $14 \ldots \ldots \ldots \ldots \ldots \ldots$ & 368 & 1,926 & 34 & 259 & 1,334 & 16 & 1,063 & 2,587 & 2,412 & +175 \\
January $15 \ldots \ldots \ldots \ldots \ldots \ldots$ & 407 & 1,921 & 34 & 259 & 1,461 & 150 & 897 & 2,621 & 2,508 & +113 \\
\hline
\end{tabular}

ture the predicted daily loss of weight would be 24 grams instead of 22 grams as in the former case.

The remaining data needed to obtain the water exchange are shown 
in table 5. With this information at hand, the values set forth in table 6 were secured. Columns 1, 2, 3 and 4 show the amounts of the various increments that make up the available water (column 8). Columns 5, 6 and 7 are the separate items of outgoing water, brought together in column 9. Finally column 10 shows how much water has been retained or lost by the organism during each 24 hours. The table also shows the effect on water exchange of each of the two ways of calculating the heat value of the diet. It is clear that the differences are not significant. ${ }^{10}$

IV

In order to estimate the degree of accuracy of this method for obtaining water exchange, a prediction of the water retention or loss for this same period has been made. This was done by comparing the actual change in weight with the theoretical loss of weight and assuming the difference to be water. See table 7. In the upper section of the table, the caloric value of the diet is calculated by means of the usual heat values assigned to food. In the lower section the caloric value of the diet is obtained by subtracting the calories lost in uripe and stool from the full heat value of the diet. It is noticeable that a marked discrepancy between the predicted and determined water balance exists on the last day, but by both methods of calculation the agreement is surprisingly good for the other four days. One may conclude from this comparison that the usual caloric values assigned to food are sufficiently accurate to give excellent values for water balance. The reason for the error on the last day is not evident, but it has been consistently noticed that on days when an unusually large stool was voided the largest errors in water balance have occurred. It should be pointed out, however, that the total error for the five days was 44 grams or a little more than 8 grams per day.

Table 8 gives a comparison between the predicted and determined water balance when the normal subject was receiving a somewhat more complicated diet than the one just dealt with. In addition to the milk mixture and sucrose he was given bread, butter, bananas and

${ }^{10}$ The heat value of the stool calculated from determinations of nitrogen, fat, ash and carbohydrate by difference, was 4.4 calories per gram of dry weight. This checks well with the value, 4.35 obtained by the oxy calorimeter. 
grape-nuts. This diet, like the one taken during the period represented by table 7, also contained more energy than the maintenance requirement. This period followed one during which the subject was living under the special conditions of the investigation except that he was allowed the "house diet." The data for calculating the water balance of this period will be found in table 1 of the appendix.

The water balance of a third period of moderate overnutrition is shown in table 9. The diet contained milk, sucrose, bread, butter

TABLE 7

Comparison between predicted and determined water balance based on daia in table 6

\begin{tabular}{|c|c|c|c|c|c|}
\hline \multirow{2}{*}{ Date } & \multirow{2}{*}{$\begin{array}{l}\text { Change } \\
\text { in subject's } \\
\text { weight }\end{array}$} & \multirow{2}{*}{$\begin{array}{c}\text { Theoretical } \\
\text { loss }\end{array}$} & \multicolumn{3}{|c|}{ Water balance } \\
\hline & & & Predicted & Determined & Error \\
\hline & grams & grams & grams & grams & grams \\
\hline January'11............. & -135 & 22 & -113 & -115 & 2 \\
\hline January $12 \ldots \ldots \ldots \ldots \ldots$ & -175 & 22 & -153 & -157 & 4 \\
\hline January $13 \ldots \ldots \ldots \ldots \ldots$ & +380 & 22 & +402 & +395 & 7 \\
\hline January $14 . \ldots \ldots \ldots \ldots$ & +150 & 22 & +172 & +169 & 3 \\
\hline January $15 \ldots .$. & +45 & 22 & +67 & +107 & 40 \\
\hline \multicolumn{3}{|c|}{ Totals $\ldots ; \ldots \ldots \ldots \ldots \ldots \ldots \ldots \ldots \ldots \ldots \ldots \ldots \ldots \ldots$} & +375 & +399 & \\
\hline January $11 \ldots \ldots \ldots \ldots \ldots$ & -135 & 24 & -111 & -109 & 2 \\
\hline January $12 \ldots \ldots \ldots \ldots \ldots \ldots$ & -175 & 24 & -151 & -151 & $\mathbf{0}$ \\
\hline January $13 \ldots \ldots \ldots \ldots \ldots \ldots$ & +380 & 24 & +404 & +401 & 3 \\
\hline January $14 \ldots \ldots \ldots \ldots$ & +150 & 24 & +174 & +175 & 1 \\
\hline January $15 \ldots \ldots \ldots \ldots \ldots \ldots$ & +45 & 24 & +69 & +113 & 44 \\
\hline \multicolumn{3}{|c|}{ 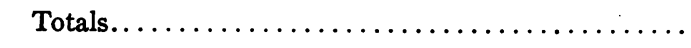 } & +385 & +429 & \\
\hline
\end{tabular}

Error for period 44

and bananas, but the "grape-nuts" were not used. This period followed one of undernutrition during which there had apparently been a depletion of glycogen since the fasting respiratory quotient had fallen to 0.72 from the earlier level of 0.82 . When the higher diet of this third period of overnutrition was taken by the subject, his quotient again rose to 0.82 , indicating that he had replaced the glycogen destroyed in the preceding period. However, when calculating the metabolic mixture used in compiling table 9 , it was assumed that the extra calories of the diet were stored as fat. It is instructive 
to see how much difference in water exchange would be caused by using a metabolic mixture based on the assumption that all the extra calories were stored as glycogen. The metabolic mixture in the first case was: protein 66 grams; fat 76 grams; carbohydrate 270 grams. In the second case it would be: protein 66 grams; fat 88 grams; carbohydrate 243 grams. The change in metabolic mixture would affect the water of oxidation, the insensible water and the preformed water. Since the preformed water held by glycogen is not known, we have left

TABLE 8

Comparison between determined and predicted water balance in overnutrition

\begin{tabular}{|c|c|c|c|c|c|}
\hline \multirow{2}{*}{ Date } & \multirow{2}{*}{$\begin{array}{l}\text { Change in } \\
\text { subject's } \\
\text { weight }\end{array}$} & \multirow{2}{*}{$\begin{array}{c}\text { Theoretical } \\
\text { loss }\end{array}$} & \multicolumn{3}{|c|}{ Water balance } \\
\hline & & & Predicted & Determined & Error \\
\hline 1928 & grams & grams & grams & grams & grams \\
\hline November $13 . \ldots \ldots \ldots \ldots \ldots \ldots$ & -475 & 22 & -453 & -433 & 20 \\
\hline November $14 \ldots \ldots \ldots \ldots \ldots \ldots$ & -175 & 22 & -153 & -161 & 3 \\
\hline November $15 \ldots \ldots \ldots \ldots \ldots \ldots$ & -470 & 22 & -448 & -402 & 46 \\
\hline November $16 \ldots \ldots \ldots \ldots \ldots \ldots$ & +415 & 22 & +437 & +423 & 14 \\
\hline November $17 \ldots \ldots \ldots \ldots \ldots \ldots$ & +85 & 22 & +107 & +133 & 26 \\
\hline November $18 . \ldots \ldots \ldots \ldots \ldots$ & -20 & 22 & +2 & -31 & 33 \\
\hline November $19 . \ldots \ldots \ldots \ldots \ldots$ & -350 & 22 & -328 & -275 & 53 \\
\hline November $20 \ldots \ldots \ldots \ldots \ldots$ & +225 & 22 & $\check{+247}$ & $\mp 255$ & 8 \\
\hline November $21 \ldots \ldots \ldots \ldots \ldots$ & -10 & 22 & +12 & +7 & 5 \\
\hline November $22 \ldots \ldots \ldots \ldots \ldots \ldots$ & +190 & 22 & +212 & +229 & 17 \\
\hline November $23 \ldots \ldots \ldots \ldots \ldots \ldots$ & -125 & 22 & -103 & -106 & 3 \\
\hline \multicolumn{3}{|l|}{ Totals. } & -468 & -361 & \\
\hline
\end{tabular}

Error for period 107

all of the preformed water out of the following calculation. While this obviously fails to give a true statement of the water exchange, it does not affect the relationship between the predicted and determined water balance. This is true because the predicted loss of weight as ordinarily calculated includes the preformed water which also makes up part of the available water. This fact comes out clearly when the two balances are compared by means of algebraic equations:

(1) Predicted water balance $=$ (Solids + Preformed Water $) \pm$ (Change in weight).

(2) Determined water balance $=$ (Preformed water + Drink + Food Water + Oxidation water) - (Outgoing water). 
If our predicted and determined balances are correct, then

Predicted water balance $=$ Determined water balance

Therefore

$($ Solids + Preformed water $) \pm($ Change in weight $)=($ Preformed water + Drink + food water + Oxidation water) - (Outgoing water)

Hence

(Solids) $\pm($ Change in weight $)=($ Drink + Food water + Oxidation water $)-$ (Outgoing water)

TABLE 9

Comparison between determined and predicted water balance when glycogen is being stored

\begin{tabular}{|c|c|c|c|c|c|}
\hline \multirow{2}{*}{ Date } & \multirow{2}{*}{$\begin{array}{c}\text { Change in } \\
\text { subject's } \\
\text { weight }\end{array}$} & \multirow{2}{*}{$\begin{array}{c}\text { Theoretical } \\
\text { loss }\end{array}$} & \multicolumn{3}{|c|}{ Water balance } \\
\hline & & & Predicted & Determined & Error \\
\hline 1928 & grams & grams & grams & grams & grams \\
\hline December $3 \ldots . .$. & +145 & -15 & +160 & +173 & 13 \\
\hline December $4 \ldots$. . & +520 & -15 & +535 & +527 & 8 \\
\hline December $5 .$. & -150 & -15 & -135 & -118 & 17 \\
\hline December $6 \ldots \ldots \ldots \ldots \ldots \ldots$ & -50 & -15 & -35 & -7 & 28 \\
\hline December $7 \ldots \ldots \ldots \ldots$. & -25 & -15 & -10 & -26 & 16 \\
\hline December $8 \ldots$ & -80 & -15 & -65 & -52 & 13 \\
\hline \multicolumn{3}{|l|}{ Totals. . } & -497 & -450 & \\
\hline
\end{tabular}

Error for period 47

A detailed statement of the water exchange for the period under consideration, showing the effect of each metabolic mixture, will be found in table 10. Consideration of table 10 brings out several points of interest: (1) If one is trying to account for the difference between the actual weight of an individual and what he would be expected to weigh as the result of any given diet, the discrepancy, due to retention or loss of water, may be determined as successfully when preformed water is left out of the account as when it is included. 
L. H. NEWBURGH, M. W. JOHNSTON AND M. FALCON-LESSES

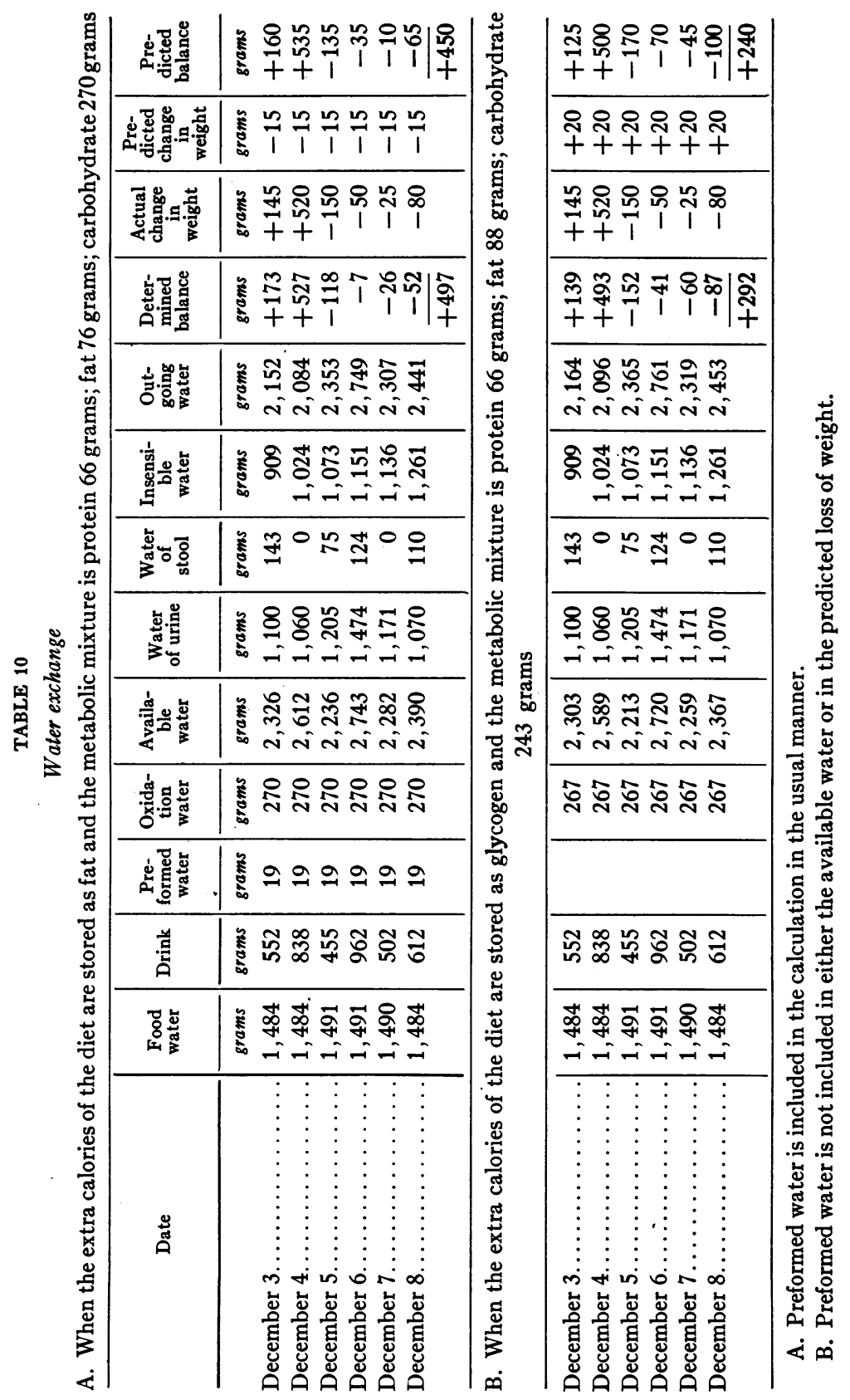


This is demonstrated in figure 1 , which represents that period ${ }^{11}$ in the study of the normal subject, when the preformed water was the largest; namely 65 grams daily. The solid line $(A)$ is the predicted weight when the predicted loss is only the weight of protein and fat destroyed; and the broken line $(B)$ is the predicted weight when the

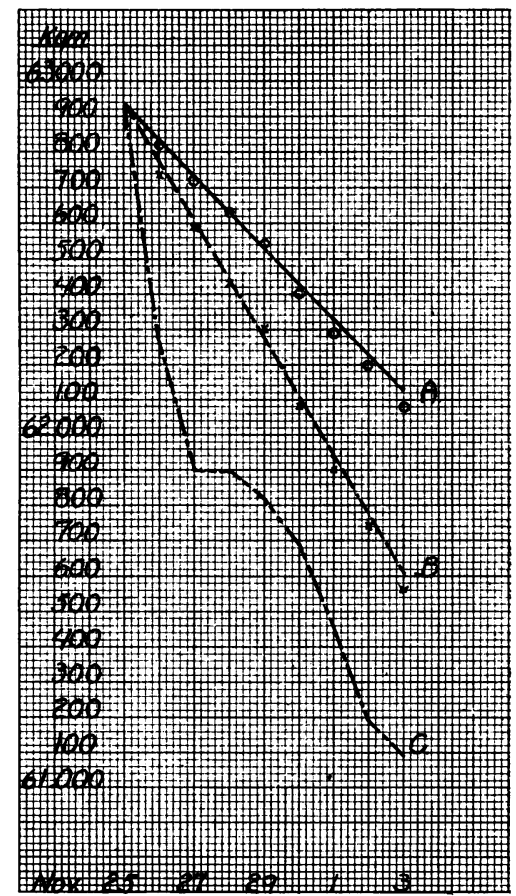

FIG. 1

$C$, actual weight of subject. $B--$, and $B \times \mathrm{x}$; predicted and corrected weight obtained in usual way. $A$-, and $A$ o o; predicted and corrected weight when no preformed water is included in the calculation.

predicted loss of weight includes the preformed water in addition to the protein and fat. The circles and crosses indicate the subject's real weight $(C)$ corrected each day by adding or subtracting the amount of water that had been held or lost by the subject. But in

${ }^{11}$ Not the same period as used for Table 10. It was the first period of undernutrition and immediately preceded that presented in table 10. 
the case of the corrections represented by the circles, the water balances used to make the corrections were the differences between the outgoing water and the available water when the latter did not include the preformed water. Hence both the predicted loss of weight $(A)$ and the water balance are reduced to the same degree. This corrected weight is as close to the predicted weight when preformed water is not considered as when it is. The difference between the determined and predicted water balance is, in each case, 46 grams for the whole period of 8 days.

TABLE 11

Comparison between predicted and determined water balance in undernutrition

\begin{tabular}{|c|c|c|c|c|c|}
\hline \multirow{2}{*}{ Date } & \multirow{2}{*}{$\begin{array}{c}\text { Change in } \\
\text { subject's } \\
\text { weight }\end{array}$} & \multirow{2}{*}{$\begin{array}{c}\text { Theoretical } \\
\text { loss }\end{array}$} & \multicolumn{3}{|c|}{ Water balance } \\
\hline & & & Predicted & Determined & Error \\
\hline 1929 & grams & grams & grams & grams & grams \\
\hline January $16 \ldots \ldots \ldots \ldots \ldots \ldots$ & -525 & 100 & -425 & -404 & 21 \\
\hline January $17 \ldots \ldots \ldots \ldots \ldots$ & -25 & 100 & +75 & +78 & 3 \\
\hline January $18 \ldots \ldots \ldots \ldots \ldots \ldots$ & -235 & 100 & -135 & -135 & 0 \\
\hline January $19 \ldots \ldots \ldots \ldots \ldots$ & -235 & 100 & -135 & -138 & 3 \\
\hline January $20 \ldots \ldots \ldots \ldots \ldots$ & -30 & 100 & +70 & +64 & 6 \\
\hline January $21 \ldots$ & -235 & 100 & -135 & -124 & 11 \\
\hline January $22 \ldots$ & -175 & 100 & -75 & -76 & 1 \\
\hline January $23 . .$. & +45 & 100 & +145 & +129 & 16 \\
\hline January $24 . .$. & -330 & 100 & -230 & -214 & 16 \\
\hline January $25 \ldots \ldots \ldots \ldots$ & -250 & 100 & -150 & -166 & 16 \\
\hline \multicolumn{3}{|c|}{ 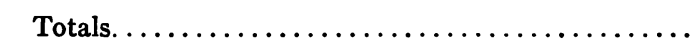 } & -985 & -966 & \\
\hline
\end{tabular}

Error for period 19 grams

(2) It is also desirable to realize that the errors in water balances found in table 10 are largely attributable to something other than an incorrect statement of the metabolic mixtures, since the errors between the predicted and determined balances are essentially the same even though the fat and carbohydrate values of the two metabolic mixtures are different.

The period represented in figure 1, was the first period of undernutrition in which water exchange was studied. The data will be found in table 3 of the appendix. That the underfeeding caused 
destruction of glycogen is clearly indicated by the fall of ten points in the respiratory quotient. It was, however, assumed, when constructing the metabolic mixture, that all of the endogenous calories came from protein and fat. The water balance thus obtained indicates that the organism lost 695 grams of water during the first two days. Most of this water was presumably released by the destruction of glycogen. If the latter has the same hydrophylic coefficient as protein, the water loss would indicate that about 200 grams of glycogen had been destroyed.

The next period, like the one represented by figure 1 , also shows the effect of the first days of undernutrition with a probable destruction of glycogen. It also followed an interval during which the subject

TABLE 12

Comparison of three periods of undernutrition in which carbohydrate in diet differed

\begin{tabular}{c|c|c|c|c|c|c|c|c}
\hline Period & Date & Protein & Fat & $\begin{array}{c}\text { Carbo- } \\
\text { hydrate }\end{array}$ & $\begin{array}{c}\text { Diet } \\
\text { calories }\end{array}$ & $\begin{array}{c}\text { Total } \\
\text { ittrogen } \\
\text { out }\end{array}$ & $\begin{array}{c}\text { Heat } \\
\text { produc- } \\
\text { tion }\end{array}$ & $\begin{array}{c}\text { Average } \\
\text { fasting } \\
\text { R.Q. }\end{array}$ \\
\hline & grams & grams & grams & calories & grams & $\begin{array}{c}\text { calories } \\
24 \text { hours }\end{array}$ & \\
\hline A & $\begin{array}{c}\text { November 25- } \\
\text { December 2 }\end{array}$ & 60 & 44 & 126 & 1,185 & 12.56 & 2,000 & 0.73 \\
B & $\begin{array}{c}\text { January 16-26 } \\
\text { C }\end{array}$ & 63 & 26 & 148 & 1,078 & 11.1 & 1,746 & 0.76 \\
\hline
\end{tabular}

was receiving more than the requirement for maintenance. The respiratory quotient fell from 0.83 during the maintenance period to 0.76. Nevertheless glycogen was not included in the metabolic mixture for reasons pointed out above. The water balance will be found in table 11, and the analytical data are brought togetherin table 4 of the Appendix. The discrepancy between the determined and predicted water balance is only 19 grams for the ten days, even though no allowance is made for the (presumable) destruction of glycogen.

It will be interesting to compare a period of undernutrition during which the diet was relatively high in carbohydrate with the two periods just discussed (fig. 1 and table 11) in which the carbohydrate was sufficiently low to (presumably) cause the organism to burn glycogen. The three periods are compared in table 12 and figure 2. While the metabolic conditions are not strictly comparable in the three periods, 
it will be noted that in period $\mathrm{A}$ in which the greatest caloric deficit exists, the dietary carbohydrate is lowest. This would imply the greatest demand upon the glycogen reserye. In period B and period C the only significant difference is in the dietary carbohydrate. This relationship between carbohydrate in the diet and the destruction of glycogen appears to be confirmed by the trend of the fasting respiratory quotient.

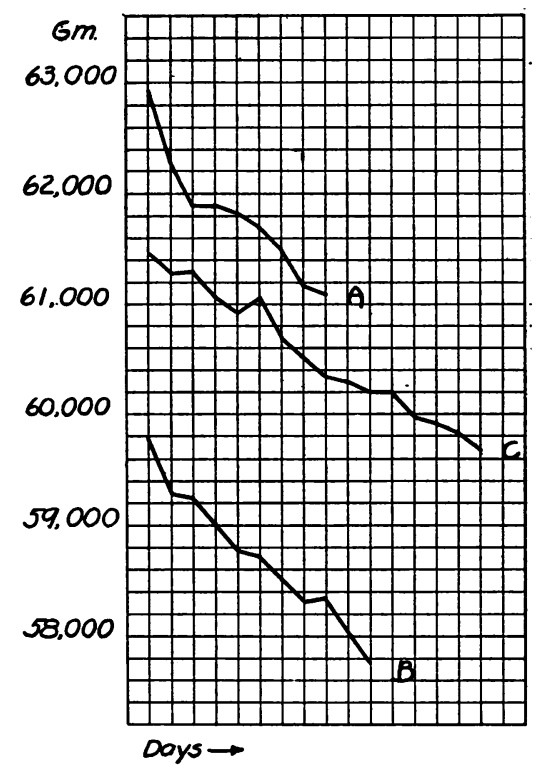

Fig. 2. Weight Curves during Three Periods of Undernutrition

The steep initial fall in $(A)$ suggests a large destruction of glycogen, whereas the relative smoothness of $(C)$ suggests that little or no glycogen was destroyed. The small but definitely steep initial fall in $(B)$ suggests a condition intermediate between $(A)$ and $(C)$.

The rapid fall in weight in period A (fig. 2) also indicates a considerable destruction of glycogen whereas in period $\mathrm{C}$, the relatively smooth curve indicates that there was no significant destruction of glycogen. The weight curve in period $B$ suggests an intermediate condition in regard to glycogen.

The water balance of this third period of undernutrition, when the dietary carbohydrate was relatively high and little or no glycogen was 
destroyed, will be found in table 13. The metabolic data for the period are brought together in table 5 of the Appendix.

The water exchange during a fourth period of undernutrition is presented next in table 14. Ten days before the beginning of this period a low calory diet consisting solely of milk and sugar was instituted and continued without change. It is probably true that the

TABLE 13

Comparison between predicted and determined water balance in undernutrition

\begin{tabular}{|c|c|c|c|c|c|}
\hline \multirow{2}{*}{ Date } & \multirow{2}{*}{$\begin{array}{l}\text { Change in } \\
\text { subject's } \\
\text { weight }\end{array}$} & \multirow{2}{*}{$\begin{array}{c}\text { Theoretical } \\
\text { loss }\end{array}$} & \multicolumn{3}{|c|}{ Water balance } \\
\hline & & & Predicted & Determined & Error \\
\hline 1928 & grams & grams & grams & grams & grams \\
\hline December $9 \ldots \ldots \ldots \ldots \ldots \ldots$ & -165 & 114 & -51 & -49 & $\dot{2}$ \\
\hline December $10 \ldots \ldots \ldots \ldots \ldots \ldots$ & +20 & 114 & +134 & +156 & 22 \\
\hline December $11 \ldots \ldots \ldots \ldots \ldots \ldots$ & -260 & 114 & -146 & -155 & 9 \\
\hline December $12 \ldots \ldots \ldots \ldots \ldots \ldots$ & -120 & 114 & -6 & +6 & 12 \\
\hline December $13 \ldots \ldots \ldots \ldots \ldots \ldots$ & +110 & 114 & +224 & +221 & 3 \\
\hline December $14 \ldots \ldots \ldots \ldots \ldots \ldots$ & -355 & 114 & -241 & -227 & 14 \\
\hline December $15 \ldots \ldots \ldots \ldots \ldots \ldots$ & -165 & 114 & -51 & -61 & 10 \\
\hline December $16 \ldots \ldots \ldots \ldots \ldots \ldots$ & -170 & 114 & -56 & -60 & 4 \\
\hline December $17 \ldots \ldots \ldots \ldots \ldots \ldots$ & -45 & 114 & +69 & +66 & 3 \\
\hline December $18 \ldots \ldots \ldots \ldots \ldots \ldots$ & -105 & 114 & +9 & +68 & 59 \\
\hline December $19 \ldots \ldots \ldots \ldots \ldots \ldots$ & \pm 0 & 114 & +114 & +104 & 10 \\
\hline December 20 . . & -230 & 114 & -116 & -128 & 12 \\
\hline December $21 \ldots$ & -50 & 114 & +64 & +76 & 12 \\
\hline December $22 \ldots \ldots \ldots \ldots \ldots \ldots$ & -105 & 114 & +9 & 0 & 9 \\
\hline December $23 \ldots \ldots \ldots \ldots \ldots \ldots$ & -140 & 114 & -26 & -33 & 7 \\
\hline December $24 \ldots \ldots \ldots \ldots \ldots \ldots$ & +130 & & +244 & +243 & 1 \\
\hline \multicolumn{3}{|l|}{ Totals. } & +174 & +227 & \\
\hline
\end{tabular}

Error for period 53 grams

destruction of glycogen had ceased before the period began, and that all the endogenous calories came from protein and fat. Since there was a falling heat production during this long period, two metabolic mixtures were calculated.

The data needed to obtain the water exchange will be found in the Appendix, tables 6 and 7. The former is for the first metabolic mixture and the latter for the second mixture. 
L. H. NEWBURGH, M. W. JOHNSTON AND M. FALCON-LESSES 181

We come now to the study of water exchange in patients. We have selected from our series what we consider to be an average example. The subject was a girl aged fourteen years, of low mentality, and who

TABLE 14

Comparison between predicted and determined water balance in undernutrition

\begin{tabular}{|c|c|c|c|c|c|}
\hline \multirow{2}{*}{ Date } & \multirow{2}{*}{$\begin{array}{l}\text { Change in } \\
\text { subject's } \\
\text { weight }\end{array}$} & \multirow{2}{*}{$\begin{array}{c}\text { Theoretical } \\
\text { loss }\end{array}$} & \multicolumn{3}{|c|}{ Water balance } \\
\hline & & & Predicted & Determined & Error \\
\hline 1929 & grams & grams & grams & grams & grams \\
\hline January $26 . \ldots \ldots \ldots \ldots \ldots \ldots$ & +50 & 127 & +177 & +175 & 2 \\
\hline January $27 . \ldots \ldots \ldots \ldots \ldots \ldots$ & -115 & 127 & +12 & +33 & 21 \\
\hline January $28 \ldots \ldots \ldots \ldots \ldots \ldots$ & -285 & 127 & -158 & -147 & 11 \\
\hline January $29 . \ldots \ldots \ldots \ldots \ldots \ldots$ & +25 & 127 & +152 & +139 & 13 \\
\hline January $30 \ldots \ldots \ldots \ldots \ldots \ldots$ & +15 & 127 & +142 & +129 & 13 \\
\hline January $31 \ldots \ldots \ldots \ldots \ldots \ldots$ & +35 & 127 & +162 & +175 & 13 \\
\hline February $1 \ldots \ldots \ldots \ldots \ldots \ldots$ & -270 & 127 & -143 & -153 & 10 \\
\hline February $2 \ldots \ldots \ldots \ldots \ldots \ldots$ & -430 & 127 & -303 & -293 & 10 \\
\hline \multicolumn{3}{|c|}{ 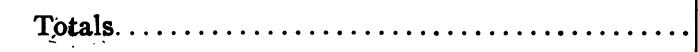 } & +41 & +58 & \\
\hline February $3 \ldots \ldots \ldots \ldots \ldots \ldots$ & +285 & 97 & +382 & +369 & 13 \\
\hline February $4 \ldots \ldots \ldots \ldots \ldots \ldots$ & -225 & 97 & -128 & -105 & 23 \\
\hline February $5 \ldots \ldots \ldots \ldots \ldots$ & +65 & 97 & +162 & +149 & 13 \\
\hline February $6 \ldots \ldots \ldots \ldots \ldots$ & -125 & 97 & -28 & -41 & 13 \\
\hline February $7 \ldots \ldots \ldots \ldots \ldots$ & +115 & 97 & +212 & +198 & 14 \\
\hline February $8 \ldots \ldots \ldots \ldots \ldots \ldots$ & -345 & 97 & -248 & -201 & 47 \\
\hline February $9 \ldots \ldots \ldots \ldots \ldots \ldots$ & -150 & 97 & -53 & -55 & 2 \\
\hline February $10 \ldots \ldots \ldots \ldots$ & -90 & 97 & +7 & -4 & 11 \\
\hline February $11 \ldots \ldots \ldots \ldots$ & -35 & 97 & +62 & +48 & 14 \\
\hline February $12 \ldots \ldots$ & -350 & 97 & -253 & -215 & 38 \\
\hline February $13 \ldots \ldots \ldots \ldots$ & +20 & 97 & +117 & +101 & 16 \\
\hline February $14 \ldots \ldots \ldots \ldots \ldots \ldots$ & -5 & 97 & +92 & +75 & 17 \\
\hline February $15 \ldots \ldots \ldots \ldots \ldots \ldots$ & -310 & 97 & -213 & -176 & 37 \\
\hline \multicolumn{3}{|c|}{ 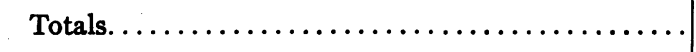 } & +108 & +143 & \\
\hline \multicolumn{3}{|c|}{ 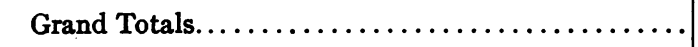 } & +149 & +201 & \\
\hline
\end{tabular}

Error for period 52 grams

had an endocrine disturbance that had caused gigantism and precocious sexual development. Her basal metabolic rate was about 25 per cent below normal. She did not cooperate well with us. She 
was fed a mixed diet of the type described on page 163; and the water content of the food was accordingly obtained by means of the duplicate diet as described on page 163. The duplicate diet was analysed for nitrogen but not for fat or carbohydrate. The food table values were used for the latter two. The urine solids were obtained by dessication in a partial vacuum over sulphuric acid. We found this method much less satisfactory than the procedure of Shackell (1).

The subject was allowed to be out of bed in a wheel chair several hours daily, but was not permitted to leave the room unless she was to be brought to the laboratory.

When the period was over it was found that the daily record of the insensible loss was unsatisfactory since the heat production obtained from it was repeatedly less than the basal metabolic rate. Upon looking back we recalled that the patient often sat in the wheel chair with bare legs in a room that, at times, was distinctly cool. The small insensible loss was apparently caused by chilling the lower extremities.

In order to compensate for this error we proceeded as follows: A few weeks after the period just described had ended, the patient was strictly confined to bed under continuous guard. Bathing was ommitted. Under these conditions the total heat production for three consecutive days was 1900,1930 , and 1930 calories. A number of determinations of the basal metabolic rate, preceding and following this special interval of three days, gave an average of 1506 calories. The total calories when the patient was continuously confined to bed were accordingly 27 per cent more than the basal calories. During the earlier period, when the insensible loss was irregular, twenty-one determinations of the basal metabolic rate gave an average of 1604 calories for 24 hours. If the total calories at this time had been 27 per cent greater, they would have been 2037. But since the patient had been more active during those days we inferred that 100 calories should be added for such factors. This gave us the final value of 2137 as the total twenty-four hourly heat production.

Before presenting the water balances for the long period when 2137 calories was assumed to be the average heat production, it is desirable to see what results were obtained during the special three day period when the heat production was so uniform. (See table 15 and Appendix, table 8.) The large error of the second day was, as usual, 
on a day when the patient had a very large stool. The considerable errors on the other two days are largely attributable to the complicated diet.

The water balances of the long period when the heat production was estimated to be 2137 calories for each twenty-four hours, are presented in table 16. (The data will be found in table 9 of the Appendix.)

In spite of the greater likelihood of larger errors for the reasons given above, the results are fairly satisfactory. From February 25th to March 12th the patient should have lost 2996 grams of weight,

TABLE 15

Water balance in a patient confined to bed but receiving a complicated diet

\begin{tabular}{|c|c|c|c|c|c|}
\hline \multirow{2}{*}{ Date } & \multirow{2}{*}{$\begin{array}{l}\text { Change in } \\
\text { subject's } \\
\text { weight }\end{array}$} & \multirow{2}{*}{$\begin{array}{c}\text { Theoretical } \\
\text { gain }\end{array}$} & \multicolumn{3}{|c|}{ Water balance } \\
\hline & & & Predicted & Determined & Error \\
\hline 1928 & grams & grams & grams & grams & grams \\
\hline April $24 \ldots \ldots \ldots \ldots \ldots \ldots \ldots$ & -157 & 7 & -164 & -134 & 30 \\
\hline April $25 \ldots \ldots \ldots \ldots \ldots \ldots$ & -565 & 7 & -572 & -517 & 55 \\
\hline April $26 \ldots \ldots \ldots \ldots \ldots \ldots \ldots \ldots$ & +129 & 7 & +122 & +100 & 22 \\
\hline Totals...... & & & -614 & -551 & \\
\hline
\end{tabular}

Error for period 63 grams

but her weight fell only 10 grams during these sixteen days. The predicted retention of water was 2886 grams and the data showed a retention of 2672 grams. Accordingly, in spite of the complicated diet and the doubt regarding the figure obtained for heat production, the determined retention of water was only 7 per cent less than the prediction.

Following the large retention of water there was an excessive output of water. During the nine days from March 12 to March 21 the patient should have lost 1629 grams. Since her weight fell 3995 grams, the difference, 2366 grams, was the predicted water loss. The determined loss was 2266 grams. In this case the determined loss was only 4 per cent less than the prediction. 
TABLE 16

Water balances when complicated diet is fed and subject is up in a chair during the day

\begin{tabular}{|c|c|c|c|c|c|}
\hline \multirow{2}{*}{ Date } & \multirow{2}{*}{$\begin{array}{l}\text { Change in } \\
\text { subject's } \\
\text { weight }\end{array}$} & \multirow{2}{*}{$\begin{array}{c}\text { Theoretical } \\
\text { loss }\end{array}$} & \multicolumn{3}{|c|}{ Water balance } \\
\hline & & & Predicted & Determined & Error \\
\hline 1928 & grams & grams & grams & grams & grams \\
\hline February $25 \ldots \ldots \ldots \ldots \ldots \ldots$ & 0 & 181 & +181 & +157 & 24 \\
\hline February $26 \ldots \ldots \ldots \ldots \ldots \ldots$ & -85 & 181 & +96 & +66 & 30 \\
\hline February $2 \pi \ldots \ldots \ldots \ldots \ldots \ldots$ & -480 & 181 & -299 & -249 & 50 \\
\hline February $28 \ldots \ldots \ldots \ldots \ldots \ldots$ & +300 & 181 & +481 & +448 & 33 \\
\hline February $29 \ldots \ldots \ldots \ldots \ldots \ldots$ & +280 & 181 & +461 & +428 & 33 \\
\hline March $1 \ldots \ldots \ldots \ldots \ldots \ldots$ & -350 & 181 & -169 & -144 & 25 \\
\hline March $2 \ldots \ldots \ldots \ldots \ldots \ldots \ldots$ & -230 & 181 & -49 & -39 & 10 \\
\hline March $3 \ldots \ldots \ldots \ldots \ldots \ldots$ & -110 & 181 & +71 & +42 & 29 \\
\hline March $4 \ldots .$. & +500 & 181 & +681 & +650 & 31 \\
\hline$\ldots \ldots \ldots \ldots \ldots \ldots$ & -290 & 181 & -109 & -48 & 61 \\
\hline March $6 \ldots . .$. & -110 & 181 & +71 & +44 & 27 \\
\hline March $7 \ldots$. & +260 & 181 & +441 & +396 & 45 \\
\hline March $8 \ldots .$. & -360 & 181 & -179 & -210 & 31 \\
\hline March $9 \ldots$. & +170 & 181 & +351 & +338 & 13 \\
\hline March $10 \ldots$ & -225 & 181 & -44 & -79 & 35 \\
\hline March $11 \ldots \ldots \ldots \ldots \ldots \ldots$ & +720 & 181 & +901 & +872 & 29 \\
\hline \multicolumn{3}{|l|}{ Totals. . } & $+2,886$ & $+2,672$ & \\
\hline March $12 \ldots$ & -665 & 181 & -484 & -411 & 73 \\
\hline March $13 \ldots$ & -90 & 181 & +91 & +71 & 20 \\
\hline March $14 \ldots .$. & -640 & 181 & -459 & -434 & 25 \\
\hline March $15 \ldots \ldots \ldots \ldots \ldots \ldots$ & -300 & 181 & -119 & -107 & 12 \\
\hline March $16 \ldots$ & -700 & 181 & -519 & -486 & 33 \\
\hline March $17 \ldots$ & -195 & 181 & -14 & -48 & 34 \\
\hline March $18 \ldots .$. & -875 & 181 & -694 & -673 & 21 \\
\hline March $19 \ldots .$. & -150 & 181 & +31 & +13 & 18 \\
\hline March $20 \ldots \ldots \ldots \ldots \ldots \ldots \ldots$ & -380 & 181 & -199 & -191 & 7 \\
\hline \multicolumn{3}{|c|}{ 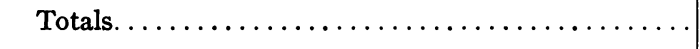 } & $-2,366$ & $-2,266$ & \\
\hline \multicolumn{3}{|c|}{ 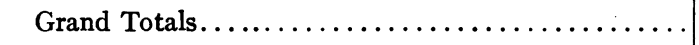 } & +520 & +406 & \\
\hline
\end{tabular}

Error for period 114 grams

V

There remains now the discussion of the degree of accuracy of the water balance obtained by the above methods. We have dealt 
with this question by comparing the predicted balance with the determined balance. This implies that the prediction is absolutely correct. But the information at hand does not warrant such an assumption to its full extent, since the predicted balance is derived from the

TABLE 17

Error in determination of water balance

\begin{tabular}{|c|c|c|c|c|c|c|}
\hline \& & \multirow[b]{2}{*}{ Date } & \multicolumn{3}{|c|}{ Daily error } & \multirow{2}{*}{ 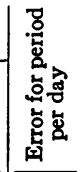 } & \multirow[b]{2}{*}{ Notes } \\
\hline 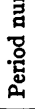 & & 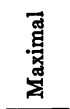 & 莺 & 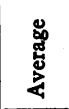 & & \\
\hline & . & grams & grams & grams & grams & \\
\hline 1 & $\begin{array}{l}\text { January } 26- \\
\text { February } 15\end{array}$ & 47 & 2 & 17 & 2.5 & $\begin{array}{l}\text { Diet completely analysed. Under- } \\
\text { nutrition. No destruction of } \\
\text { glycogen }\end{array}$ \\
\hline 2 & December 9-24 & 57 & 2 & 12 & 3.3 & $\begin{array}{l}\text { Diet completely analysed. Under- } \\
\text { nutrition. Little or no destruction } \\
\text { of glycogen }\end{array}$ \\
\hline 3 & January 16-25 & 21 & 0 & 9 & 1.9 & $\begin{array}{l}\text { Diet completely analysed. Under- } \\
\text { nutrition. Moderate destruction } \\
\text { of glycogen }\end{array}$ \\
\hline 4 & $\begin{array}{l}\text { November 25- } \\
\text { December } 2\end{array}$ & 37 & 4 & 12 & 5.7 & $\begin{array}{l}\text { Diet completely analysed. Under- } \\
\text { nutrition. Much glycogen de- } \\
\text { stroyed }\end{array}$ \\
\hline 5 & December 3-8 & 28 & 8 & 16 & 7.8 & $\begin{array}{l}\text { Diet completely analysed. Overnu- } \\
\text { trition. Much glycogen stored }\end{array}$ \\
\hline 6 & November 13-23 & 53 & 3 & 21 & 9.7 & $\begin{array}{l}\text { Diet completely analysed. Overnu- } \\
\text { trition. No data regarding glycogen }\end{array}$ \\
\hline 7 & January 11-15 & 40 & 2 & 11 & 4.8 & $\begin{array}{l}\text { Diet completely analysed. Overnu- } \\
\text { trition. No data regarding gly- } \\
\text { cogen }\end{array}$ \\
\hline 8 & April 24-26 & 55 & 22 & 36 & 21.0 & $\begin{array}{l}\text { Only nitrogen of diet determined. } \\
\text { Duplicate diet used. Overnutri- } \\
\text { tion. Period only three days }\end{array}$ \\
\hline 9 & $\begin{array}{l}\text { February 25- } \\
\text { March } 20\end{array}$ & 73 & 7 & 30 & 4.6 & $\begin{array}{l}\text { Only nitrogen of diet determined. } \\
\text { Duplicate diet used. Undernutri- } \\
\text { tion. Small destruction of gly- } \\
\text { cogen }\end{array}$ \\
\hline
\end{tabular}

metabolic mixture and it usually is not possible to avoid small inaccuracies in the latter. Accordingly the error, as the term is used in table 17, is not a final measure of the method; but is an approximation, approaching nearest to the truth when the statement of the metabolic mixture is most nearly correct. 
In period 1 of table 17 , the conditions were most suitable for obtaining a satisfactory statement of the materials burned. The values for period 1 may, therefore, be accepted as the probable error of the method.

The conditions for period 2 are only slightly different from those of period 1 ; so that the error is nearly the same.

It will be seen that the average error is only about 15 grams per day, but that a mistake of $\mathbf{5 0}$ grams may occur on any single day. Since the water that the subject had to deal with from day to day was about 2100 grams, the average error made in accounting for it was less than 1 per cent; and, what is more important, the maximal error was less than 3 per cent.

Interestingly the errors for periods 3 and 4 , when the metabolic mixture cannot be correct because it does not include the glycogen that was destroyed, are no greater. Likewise, in the three periods of overnutrition, periods 5, 6 and 7 in the table, when the same doubt exists regarding glycogen, the error is of only slightly greater magnitude than in period 1.

The two periods 8 and 9 , when the conditions were not so simple nor so satisfactory, gave results that are better than anticipated.

The last column of table 17 deals with the error in water balance for whole periods, expressed in 24 hourly amounts. This is not the same as the average error, since the daily differences tend to counteract each each other and so reduce the discrepancy. The error in determining the water balance for the period was always less than 0.5 per cent of the water to be dealt with, except in period 8 where the period is too short to be of much value in this regard.

\section{BIBLIOGRAPHY}

1. Shackell, L. F., Am. J. Physiol., 1909, xxiv, 325. An Improved Method of Desiccation with Some Applications to Biological Problems.

2. DuBois, E. F., Basal Metabolism in Health and Disease, 2nd ed., Lea \& Febiger, Philadelphia, 1927, pp. 24, 29, 216.

3. Johnston, M. W., and Newburgh, L. H., J: Clin. Invest., 1929, viii, 147. The Determination of the Heat Eliminated by the Human Being.

4. Lusk, G., Elements of the Science of Nutrition, 3rd ed., W. B. Saunders Co., Philadelphia, 1917, p. 39. 
5. Isenschmid, Med. Klin., 1918, xiv, 1128. Die Bestimmung der wasserbilanz am Krankenbett.

6. Schwenkenbecher, A., and Inagaki, Arch. fur Exper. Path., u., Pharmacol., 1906, liv, 168. Ueber den Wasserwechsel des fiebernden Menschen.

7. Benedict, F. G., and Fox, E. L., J. Biol. Chem., 1925, lxvi, 783. A Method for the Determination of the Energy Values of Foods and Excreta. 


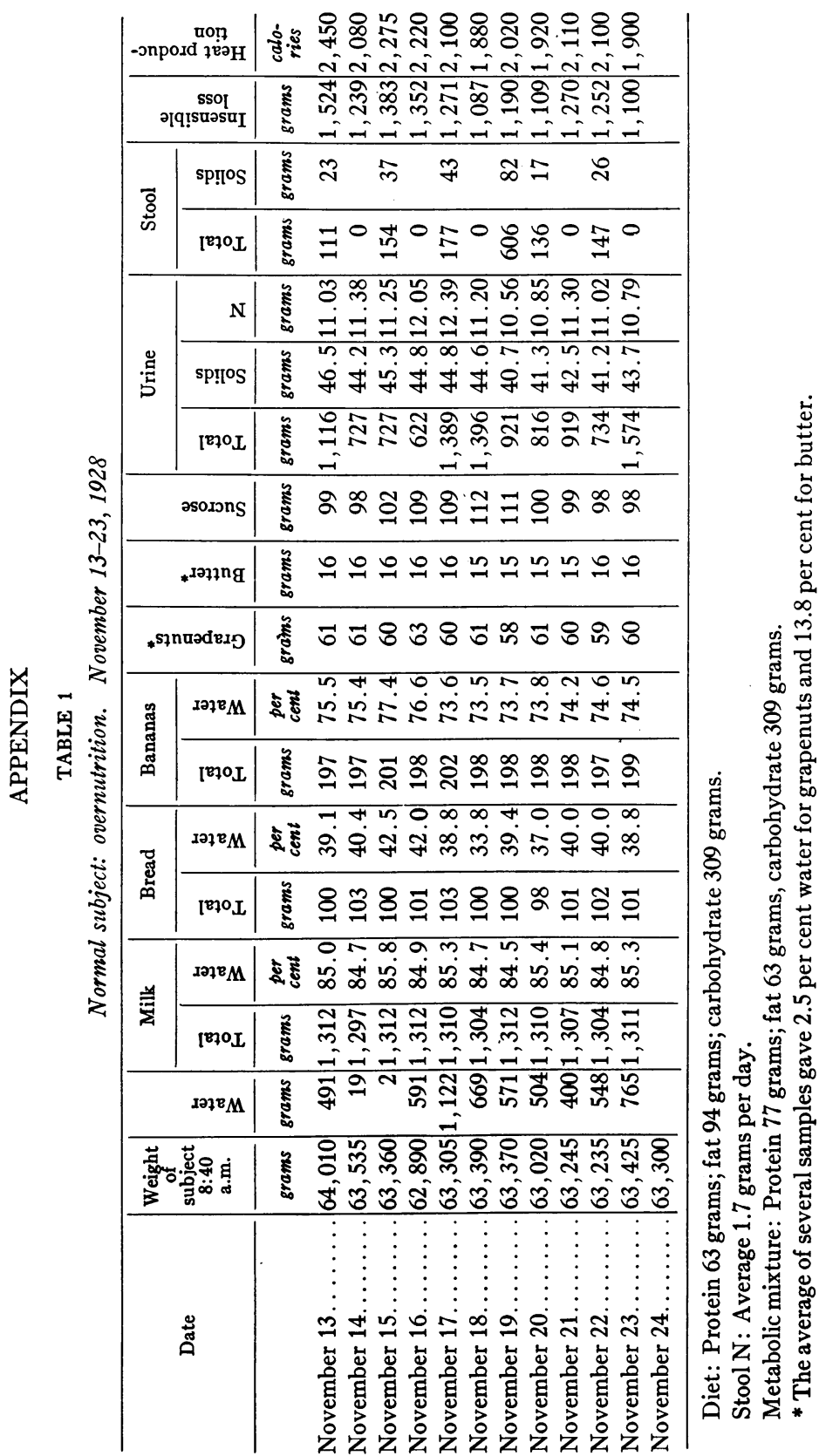


L. H. NEWBURGH, M. W. JOHNSTON AND M. FALCON-LESSES 189

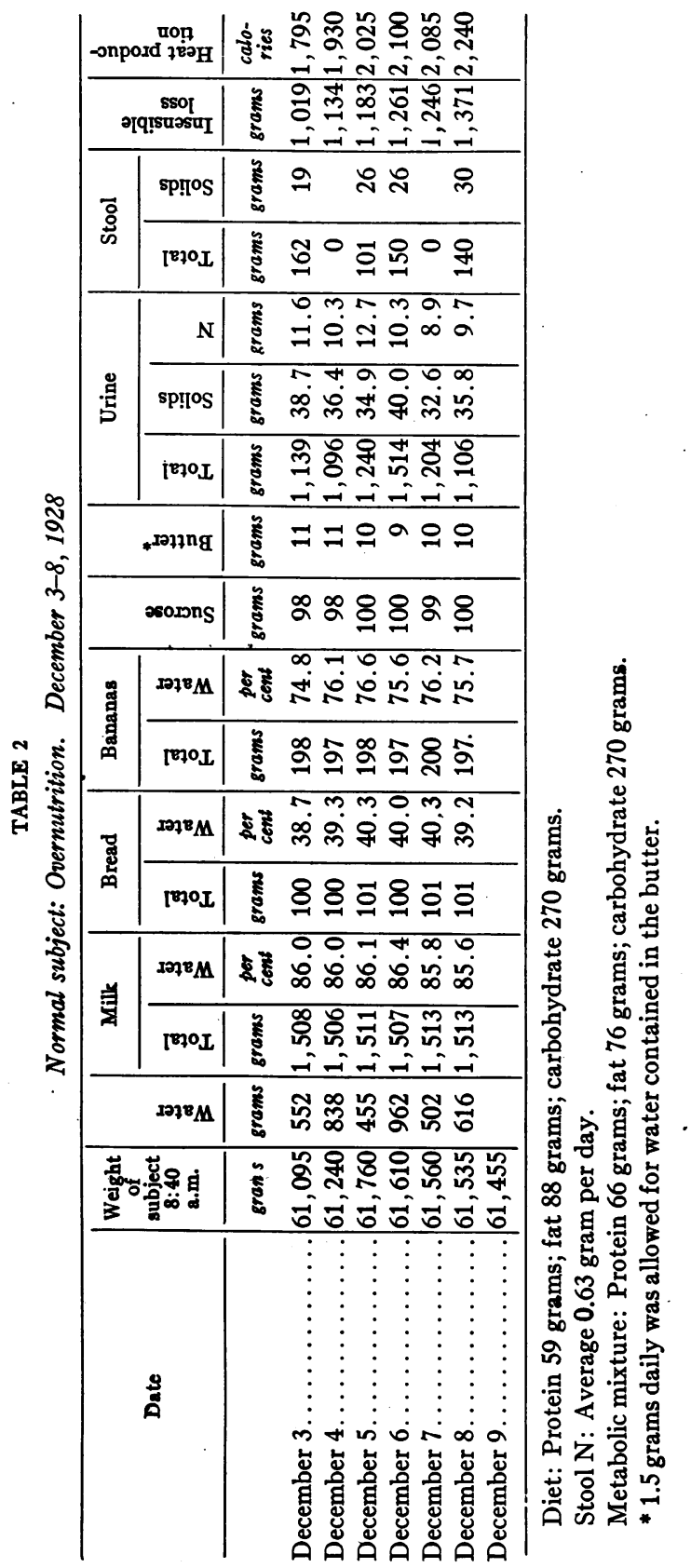




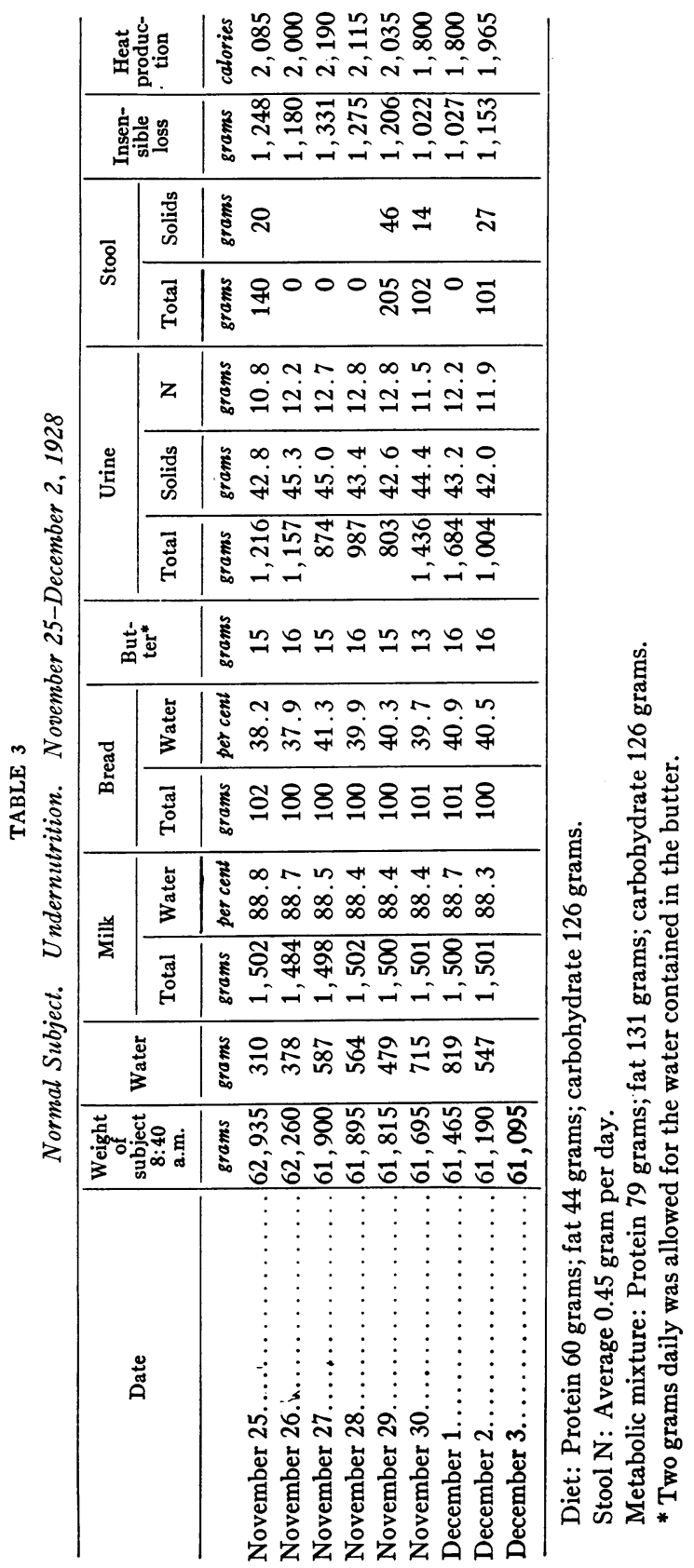


L. H. NEWBURGH, M. W. JOHNSTON AND M. FALCON-LESSES 191

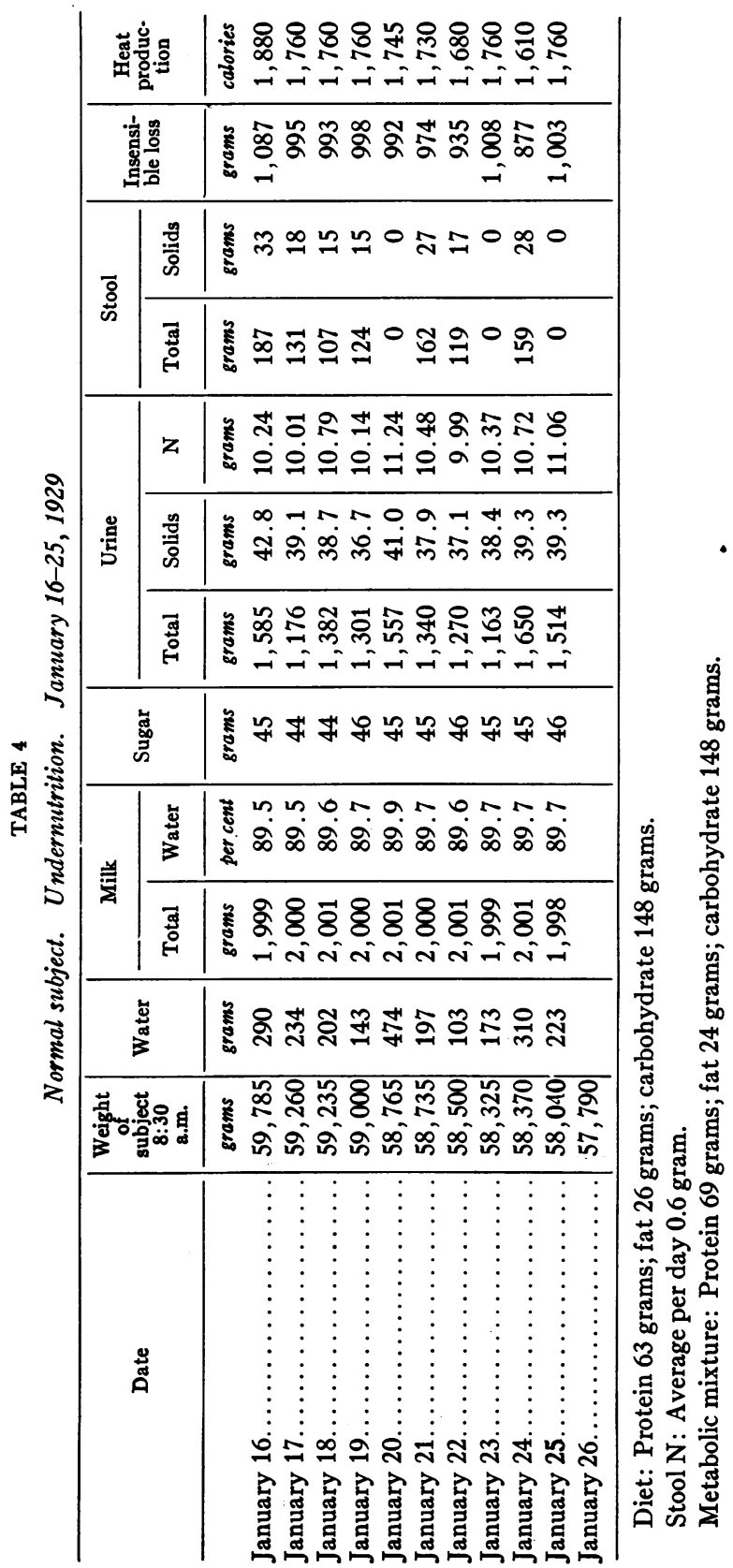




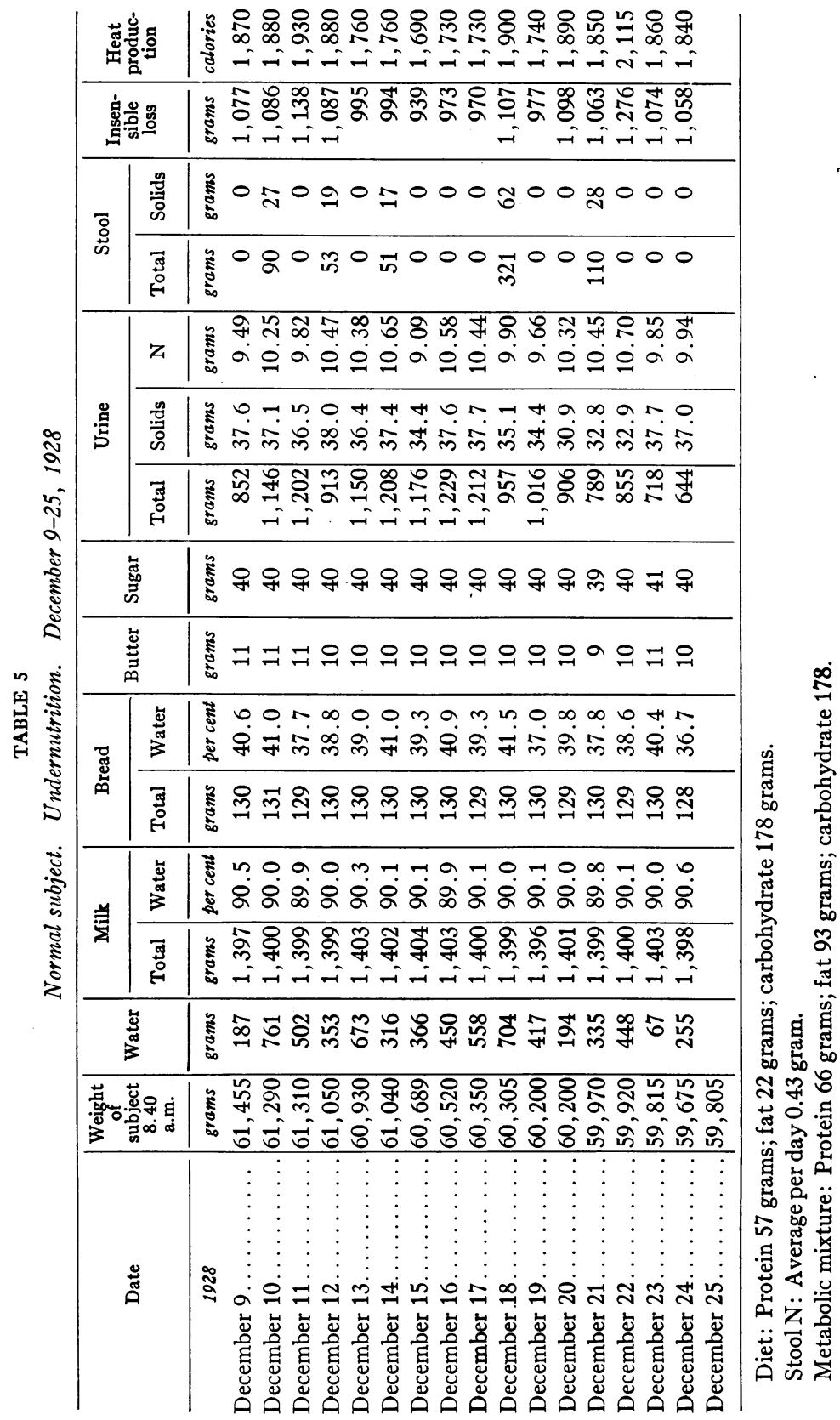




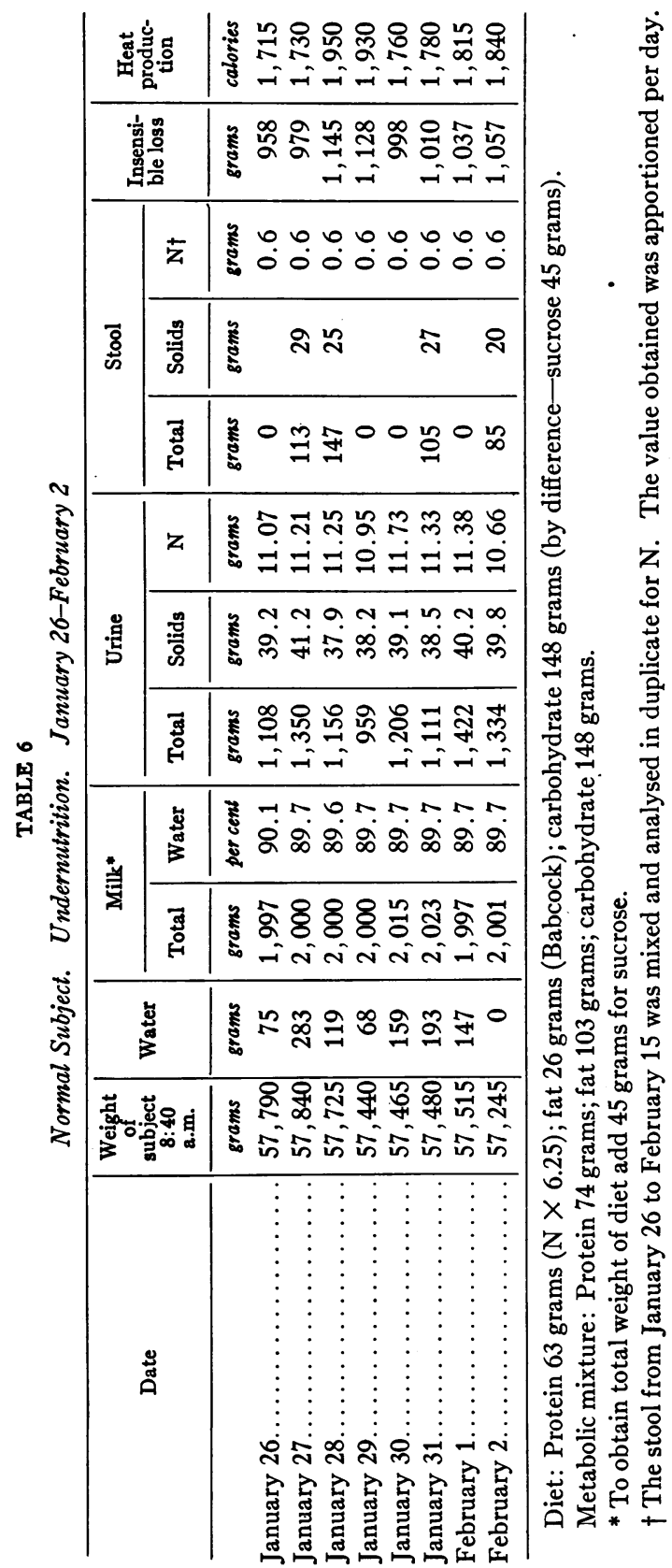




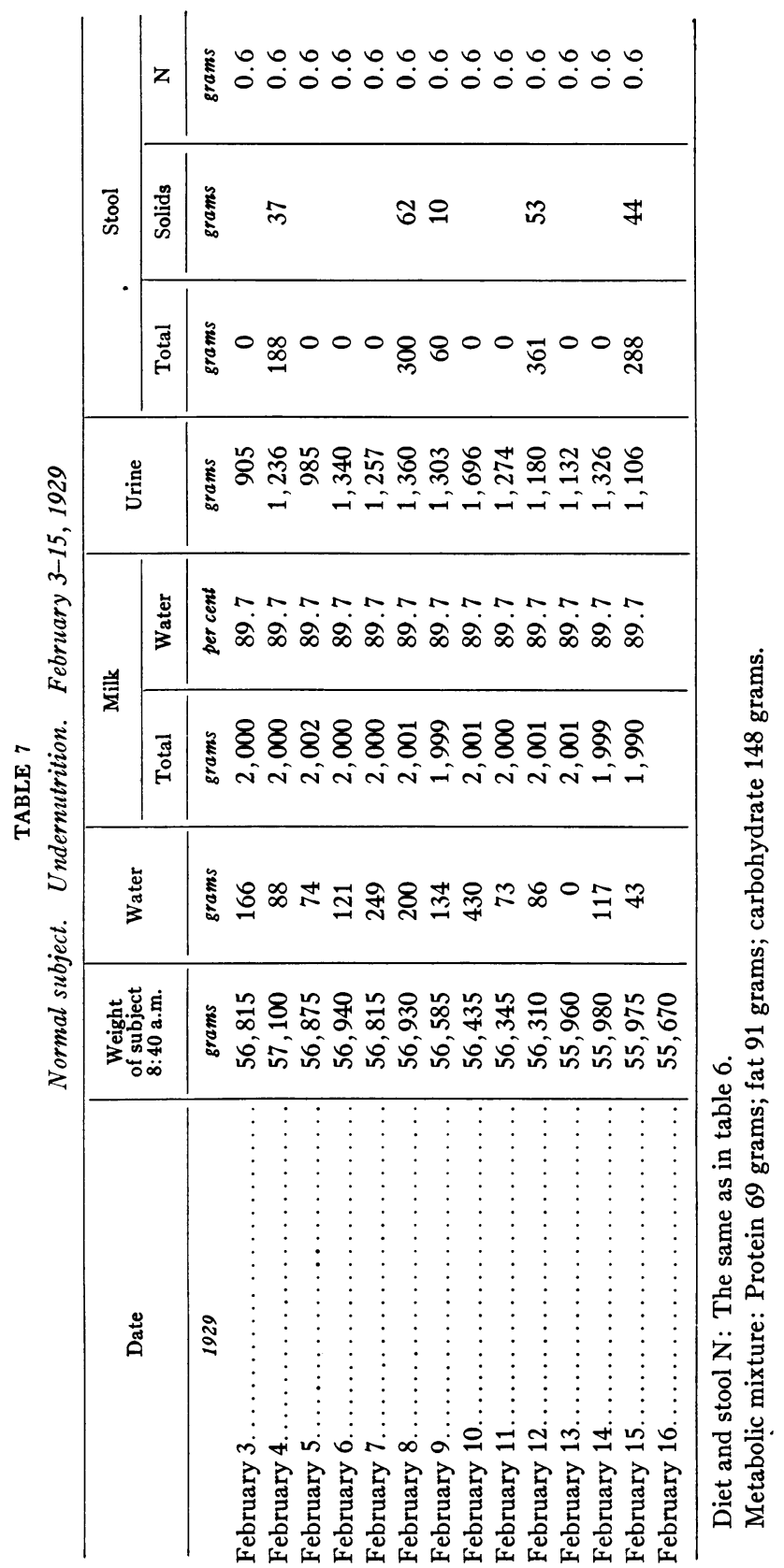


L. H. NEWBURGH, M. W. JOHNSTON AND M. FALCON-LESSES 195

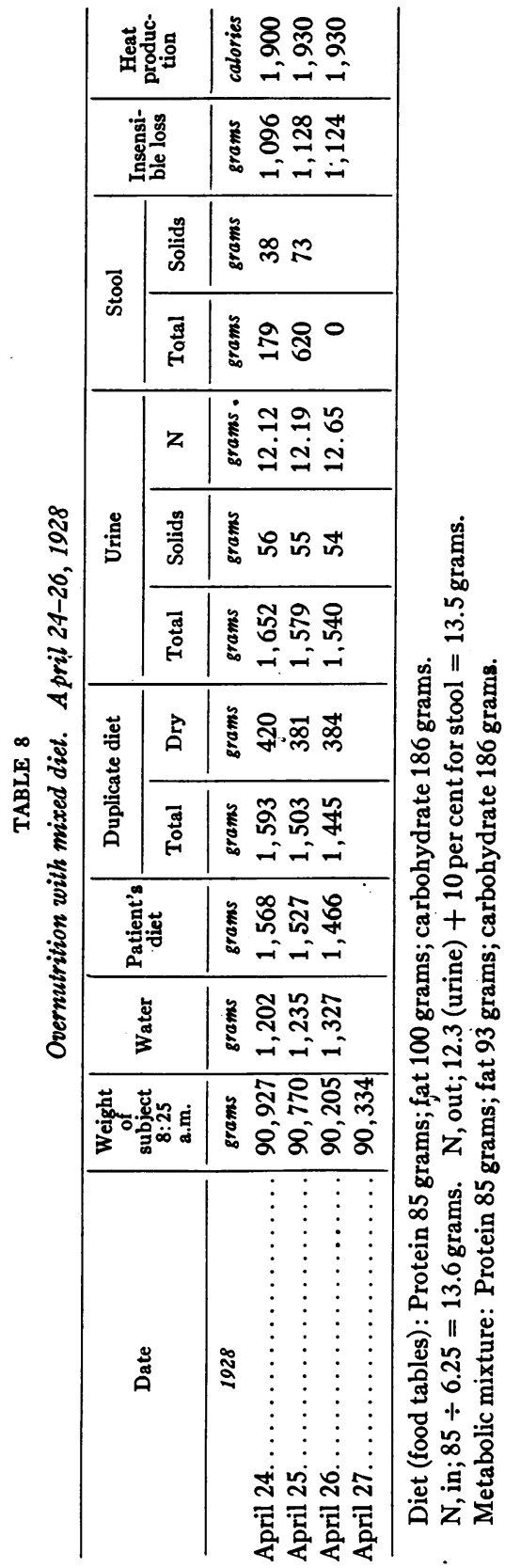




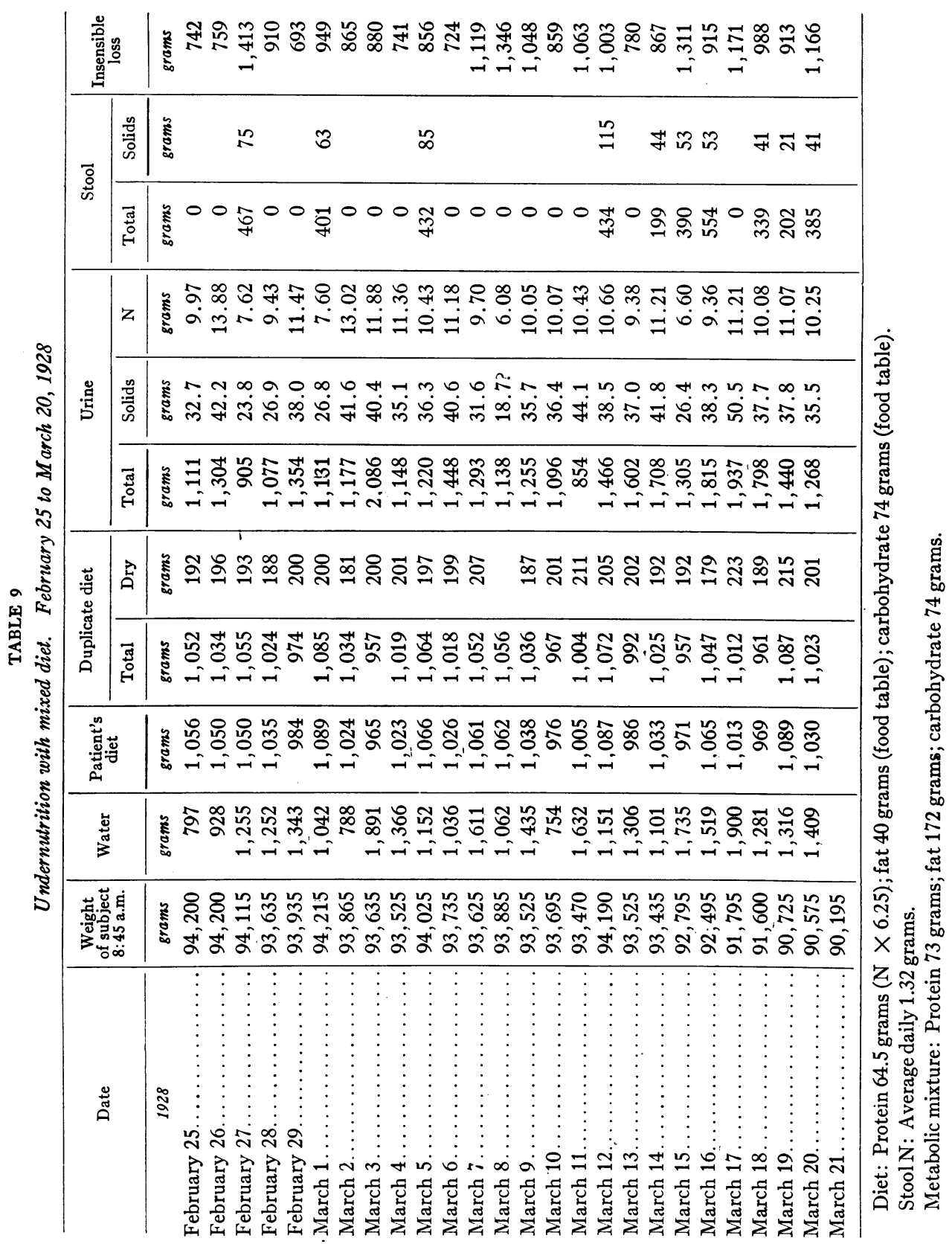

